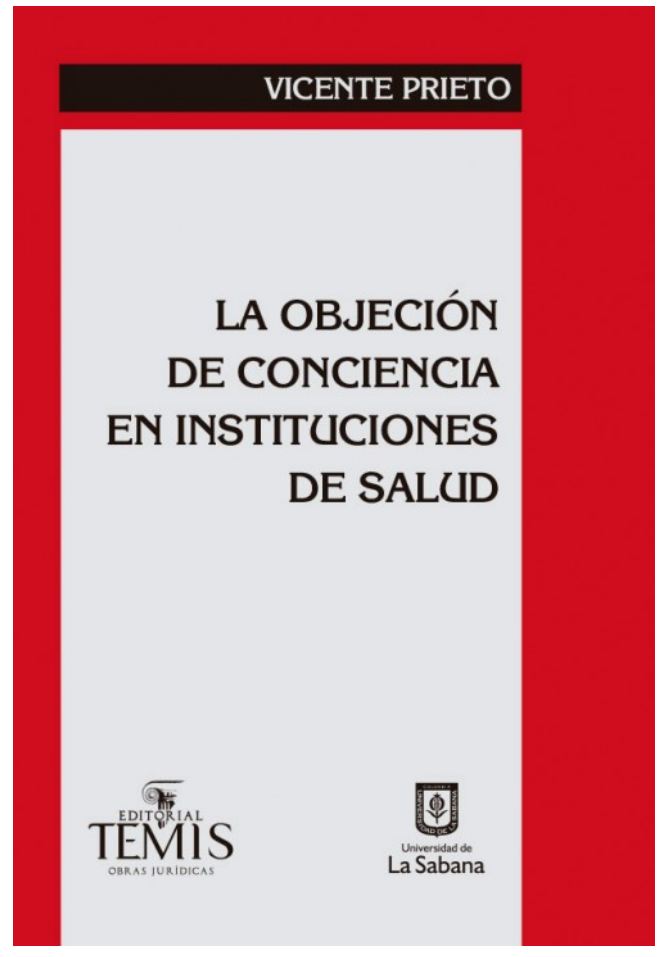

\title{
LA OBJECION DE CONCIENCIA EN INSTITUCIONES DE SALUD
}

\author{
Por: Vicente Prieto \\ Formato: Impreso \\ ISBN: 978-958-35-0945-2 \\ Facultad: Derecho y Ciencias Políticas \\ Coeditor: Editorial Temis \\ Idioma: Español \\ Precio en dólares: USD $\$ 7,00$ \\ Número de páginas: 136 \\ $\$ 22.000$
}

\section{Reseña del Producto}

La expresión "objeción de conciencia institucional" resulta problemática por ser la conciencia un atributo de la persona individual, no de las instituciones. El asunto no es si la institución tiene o no conciencia, sino cuáles son sus derechos en relación con las libertades de pensamiento, de conciencia y de religión. Para el autor, la extensión a las personas jurídicas del reconocimiento de derechos que, en principio, pertenecen a la persona, como el derecho al buen nombre y a la libertad religiosa, entre otros, es un ejercicio típico de extensión analógica, usado sin dificultad en múltiples ámbitos del derecho. Negar a clínicas y hospitales la posibilidad de oponerse institucionalmente al aborto porque la objeción de conciencia es exclusividad de la persona individual ignora que estamos en el terreno de la analogía.

\section{Información Adicional}

\author{
Peso: $1 \mathrm{~kg}$
}

Tamaño: $13.5 \times 20.5 \times 2 \mathrm{~cm}$

Sku: 9789583509452

\section{Tabla de contenido}

\section{CAPÍTULO I INTRODUCCIÓN. LA SENTENCIA C-355 DE 2006}

CAPÍTULO II ABORTO Y OBJECCIÓN DE CONCIENCIA EN LA JURISPRUDENCIA POSTERIOR DE LA CORTE CONSTITUCIONAL

CAPÍTULO III ALGUNAS REFLEXIONES CRÍTICAS

1. Objeción de conciencia: entre la desconfianza estatal y el interés privado

2. Aborto y servicio militar

3. Del delito al derecho

4. Objeción de conciencia y resistencia civil

5. Laicismo vs. Laicidad

CAPÍTULO IV LOS DERECHOS FUNDAMENTALES DE LAS PERSONAS JURÍDICAS 
1. Jurisprudencia de la Corte Constitucional

2. La libertad religiosa

3. El derecho de asociación

4. Conclusiones

CAPÍTULO V ELEMENTOS DE DERECHO COMPARADO

1. La Unión Europea

2. Estados Unidos

3. Italia

4. España

5. Otros países

CAPÍTULO VI CONSIDERACIONES FINALES

BIBLIOGRAFÍA 